\title{
The influence of vitamin A status on iron-deficiency anaemia in anaemic adolescent schoolgirls in Myanmar
}

\author{
Min Kyaw Htet ${ }^{1,2, *}$, Umi Fahmida', Drupadi Dillon ${ }^{1,3}$, Arwin Akib ${ }^{3}$, Budi Utomo ${ }^{4}$ and \\ David I Thurnham ${ }^{5}$ \\ ${ }^{1}$ South East Asian Ministers of Education Organization, Regional Center for Food and Nutrition, University of \\ Indonesia, Salemba Raya 6, Jakarta 10430, Indonesia: ${ }^{2}$ Department of Health, Ministry of Health, Nay Pyi \\ Taw, Myanmar: ${ }^{3}$ Faculty of Medicine, University of Indonesia, Jakarta, Indonesia: ${ }^{4}$ Faculty of Public Health, \\ University of Indonesia, Depok, Indonesia: ${ }^{5}$ Northern Ireland Centre for Food and Health, School of Biomedical \\ Science, University of Ulster, Coleraine, UK
}

Submitted 12 September 2012: Final revision received 22 August 2013: Accepted 2 September 2013: First published online 16 October 2013

\begin{abstract}
Objective: The present study was conducted to investigate reasons for the high prevalence of anaemia among adolescent schoolgirls and to elucidate the role of vitamin A in contributing to Fe-deficiency anaemia (IDA).

Design: Among 1269 schoolgirls who were previously screened for anaemia $(\mathrm{Hb}<120 \mathrm{~g} / \mathrm{l}), 391$ anaemic girls were further assessed for Fe, vitamin A and subclinical inflammation status. Fe and vitamin A indicators were corrected for inflammation and were compared in the Fe-deficient and non-deficient groups as well as between those with and without inflammation. Logistic regression was done to determine whether vitamin A status and subclinical inflammation were risk factors for Fe deficiency. The differences in Fe status among tertiles of vitamin A concentrations were assessed using ANOVA.

Setting: Myanmar.

Subjects: Adolescent schoolgirls ( $n$ 391).

Results: One-third of the anaemia $(30 \cdot 4 \%)$ was IDA. Prevalence of low vitamin A status (serum retinol $<1.05 \mu \mathrm{mol} / \mathrm{l}$ ) was $31.5 \%$. Fe and vitamin A status were significantly different between the IDA and non-IDA groups and also based on their inflammation status. Logistic regression showed that low vitamin A status was a significant predictor for being Fe deficient (OR $=1 \cdot 81 ; 95 \%$ CI $1 \cdot 03,3 \cdot 19$ and $\mathrm{OR}=2 \cdot 31 ; 1 \cdot 31,4.07$ in the middle $(1 \cdot 056-1 \cdot 298 \mu \mathrm{mol} / \mathrm{l})$ and low $(\leq 1 \cdot 056 \mu \mathrm{mol} / \mathrm{l})$ vitamin A tertiles, respectively). ANOVA showed that better Fe status was associated with a higher concentration of serum retinol but only in IDA.

Conclusions: Fe deficiency was not the main cause of anaemia in the present population. The role of vitamin A as well as other micronutrients should be taken into account in addressing the problem of anaemia.
\end{abstract}

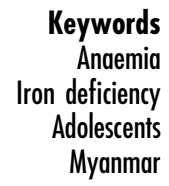

Adolescence is a period of vulnerability as well as opportunity. Myanmar, also known as Burma, is a country in the South-East Asia region where about 20\% of the demographic is adolescent and will be the future economic force of the country ${ }^{(1)}$. Anaemia is one of the major nutritional problems in the region as well as in the country and affects all age groups, especially children and women ${ }^{(2)}$. Studies have shown that preconceptional anaemia is a significant predictor of poor pregnancy outcomes $^{(3,4)}$ and thus preconceptional anaemia and $\mathrm{Fe}$ status of young women is a focus of our recent research. However, health and nutritional status information is limited for this age group. In the recently conducted survey in the delta region of Myanmar among 1269 adolescent schoolgirls, we showed that the prevalence of anaemia was $59 \cdot 1 \%^{(5)}$. In the present paper we give further information on the $\mathrm{Fe}$ and vitamin A status among these anaemic girls.

Although Fe deficiency (ID) is a major cause of anaemia, other micronutrient deficiencies can also contribute, be equally important and coexist with ID $^{(6-8)}$. Adolescence is a period of growth and development in which the growth is faster than at any other time in an individual's life, except the first year. This imposes a high demand for energy and nutrients. Through modulation of $\mathrm{Fe}$ metabolism, haematopoiesis and susceptibility to infection, vitamin A is believed to play a significant role in the development of anaemia $^{(9)}$. Trials have shown that vitamin A supplements 
have synergetic effects with Fe on anaemia and indicated that the supplements should be combined for greater effectiveness $^{(10,11)}$. However, some studies could not find any benefit from vitamin A on Fe supplementation ${ }^{(12)}$. Nutritional status indicators of Fe and vitamin A are often misinterpreted in the presence of subclinical inflammation (SCI) and markers of inflammation should always be measured for correct interpretation ${ }^{(13-15)}$. Therefore, a closer look at the association of $\mathrm{Fe}$ and vitamin $\mathrm{A}$ in relation to anaemia is still necessary and because the causes of anaemia are multifactorial, the contribution of other micronutrients and SCI should be sought wherever possible.

In South-East Asia, tropical diseases such as malaria, dengue and haemorrhagic fever, worm infestations and genetic $\mathrm{Hb}$ disorders are common and all contribute to anaemia $^{(16,17)}$. In Myanmar, reports show that malaria and dengue fever are the leading causes of morbidity and mortality and worm infestations are also common in the country ${ }^{(18,19)}$. The present study was conducted to investigate the factors contributing to the high prevalence of anaemia among adolescent schoolgirls in Myanmar and particularly the interdependence of vitamin A and Fe status in contributing to anaemia. In the present paper we report on the biochemical assessment of Fe and vitamin A status and anthropometry among anaemic adolescent schoolgirls from Myanmar and investigate the influence of vitamin A on Fe-deficiency anaemia (IDA).

\section{Participants and methods}

The data described in the present study were collected at the baseline of an intervention study conducted in the delta region of Myanmar (ClinicalTrials.gov ID: NCT 01198574). The objective of the intervention study was to investigate the role of SCI on the Fe and vitamin A status of anaemic girls during Fe supplementation. The present paper describes the baseline Fe, vitamin A and inflammation status of the girls prior to the supplementation.

\section{Study site}

The study was conducted in Nyaung Done Township, a peri-urban area in Ayeyarwady Division in the delta region of Myanmar where the highest prevalence of anaemia was reported to exist. It is located about a $3 \mathrm{~h}$ drive away ( $\sim 40 \mathrm{~km}$ distance) from the former capital city of Yangon.

\section{Participants}

The participants were recruited in July 2010. The sample size was based on the requirements for the intervention study. It was calculated in order to detect a mean difference in $\mathrm{Hb}$ of $5 \mathrm{~g} / \mathrm{l}$ between two groups, with $95 \%$ power at $5 \%$ level of significance based on a previous study in Indonesia ${ }^{(20)}$. The sample size was seventy-three for each group and allowed for a dropout rate of $20 \%$. To take account of inflammation, the sample was increased to 100 and a total of 402 participants for four intervention groups were recruited.

Before the recruitment for the baseline study, a screening for anaemia and haemoglobinopathies was conducted among the adolescent schoolgirls ( $n$ 1269) from six schools in the township ${ }^{(5)}$. Postmenarcheal schoolgirls with anaemia $(\mathrm{Hb}<120 \mathrm{~g} / \mathrm{l})$, not suffering from any major illness or disease at the time of data collection, were invited to join the study. Those with severe anaemia $(\mathrm{Hb}<70 \mathrm{~g} / \mathrm{l})$ or those who took multivitamin supplements regularly for past three months were excluded ${ }^{(2)}$. The girls with severe anaemia were treated with $\mathrm{Fe}$ and not included in the study. Deworming with a single dose of albendazole $(400 \mathrm{mg})$ was done in these girls one week before the blood collection. This treatment has been shown previously to effectively remove most gut parasites ${ }^{(21,22)}$ and we did not follow up to determine the effectiveness.

Ethical approval for the study was granted from the Faculty of Medicine, University of Indonesia (128/PT 02.FK/ETIK/2010) and from the Department of Medical Research, Lower Myanmar (18/Ethics 2010 DMR-Lower Myanmar). The parents or caregivers were informed of the objectives of the study and their informed consent was obtained. The girls were also informed and the objectives and procedures in the study were explained. Those who fulfilled the inclusion criteria and gave their consent were invited to join the study.

\section{Biochemical assessment}

Phlebotomy was done by experienced nurses and $3 \mathrm{ml}$ of non-fasting venous blood was taken from each participant in the morning school session. The blood samples were collected into non-heparinised vacuettes as well as into EDTA tubes and transported in ice-cooled containers to the laboratory of the Department of Medical Research, Lower Myanmar, within $4 \mathrm{~h}$. Haemoglobin was measured using the EDTA-treated venous blood by the cyanmethaemoglobin method at the Nutrition Research Division, Department of Medical Research, Lower Myanmar. The Hb assessment was counter-checked with three different levels of external control (high, medium, low) from the National Health Laboratory on a daily basis and the $\mathrm{CV}$ of the assessment was $\leq 5 \cdot 0 \%$. After separation, serum samples were frozen in polyethylene vials and stored at $-20^{\circ} \mathrm{C}$ for 3 months before further analyses were done. During the transport, the serum samples were packed in dry ice and kept frozen throughout the shipment to the laboratory of the SEAMEO-Regional Centre for Food and Nutrition, University of Indonesia, Jakarta, Indonesia. HPLC was used to measure serum retinol ${ }^{(23)}$. The international certified NIST standards (National Institute of Standards and Technology, Gaithersburg, MD, USA) were used for quantification and the CV for the assessment was $4.94 \%$. An in-house sandwich ELISA was used to measure serum ferritin (SF), soluble transferrin receptor (sTfR), retinol-binding 
protein (RBP), C-reactive protein (CRP) and $\alpha_{1}$-acid glycoprotein (AGP) in $200 \mu$ l of serum ${ }^{(24)}$. For the quality assurance, certified quality control samples from the Centers for Disease Control and Prevention (Atlanta, GA, USA) and Bio-Rad Liquicheck controls (Bio-Rad, Munich, Germany) were used. The CV for all measurements were $\leq 5.0 \%(3.68 \%, 3.00 \%, 2.91 \%, 4.68 \%$ and $3.30 \%$ for $\mathrm{SF}$, sTfR, RBP, CRP and AGP, respectively). Body Fe store was calculated using the method of Cook et al. ${ }^{(25)}$ which has been applied across different age groups ${ }^{(26)}$.

\section{Definition of Fe deficiency, Fe-deficiency anaemia, vitamin A deficiency, low vitamin A store and subclinical inflammation}

Anaemia was defined when $\mathrm{Hb}$ was $<120 \mathrm{~g} / \mathrm{l}^{(27)}$, ID when SF was $<15 \mu \mathrm{g} / 1$ and/or sTfR was $>8.5 \mathrm{mg} / \mathrm{l}$, and IDA by the occurrence of ID and anaemia ${ }^{(28,29)}$. A high risk of vitamin A deficiency was defined when serum retinol or RBP concentration was $<0.7 \mu \mathrm{mol} / \mathrm{l}$ and low vitamin A status was defined when retinol or RBP concentration was $<1.05 \mu \mathrm{mol} / \mathrm{l}^{(30)}$. SCI was defined when serum CRP concentration was $>5 \mathrm{mg} / \mathrm{l}$ and/or AGP concentration was $>1 \mathrm{~g} / \mathrm{l}^{(13,14)}$. Participants were grouped into four categories according to their acute-phase proteins CRP and AGP: (i) healthy (both CRP and AGP normal); (ii) incubation (CRP high and AGP normal); (iii) acute convalescence (both CRP and AGP high); and (iv) late convalescence (CRP normal and AGP high). The values of serum retinol and SF were corrected using meta-analysis correction factors obtained from Thurnham et al. ${ }^{(13,14,31)}$.

\section{Dietary assessment}

Three non-consecutive-day estimated food records were recorded by the participants after explanation on how to complete the form by the Principal Investigator (M.K.H.). Participants were given pictures to help them choose the closest portion size (in household measure units) which were later converted into gram intakes. Dietary intake data were entered into Nutrisurvey software (www. nutrisurvey.de) to calculate usual dietary $\mathrm{Fe}$ intake, i.e. the average of the three days. The nutrient composition database from the Myanmar food composition table was used, supplemented with data from the Indonesian food composition table.

\footnotetext{
Anthropometry assessment

Anthropometric assessments were carried out by trained persons. Body weight was measured using a flat electronic weighing scale (SECA 874, Hamburg, Germany) to the nearest $0 \cdot 1 \mathrm{~kg}$ and height measured by a measuring tape (Microtoise SECA 206) to the nearest $0 \cdot 1 \mathrm{~cm}$. Nutritional status was assessed using Z-scores and the WHO AnthroPlus software was used for the analysis. Stunting was defined when height-for-age $Z$-score was $<-2$ and thinness was defined as BMI-for-age $Z$-score of $<-2^{(32)}$. BMI was weight divided by the square of the height $\left(\mathrm{kg} / \mathrm{m}^{2}\right)$.
}

\section{Statistical analysis}

Descriptive data were presented as means or geometric means with their standard deviations for continuous variables and as proportions for categorical data. Normality was checked with the Kolmogorov-Smirnov test and data were transformed if not normally distributed. Hb, body Fe store, serum retinol and RBP were normally distributed and SF and sTfR concentrations were transformed using logarithms. Analysis of the difference in plasma concentrations of $\mathrm{Fe}$ and vitamin A status indicators between groups was done using ANOVA or the independent-sample $t$ test in both logtransformed and arithmetic data. Post hoc analysis using least significant difference was applied when ANOVA was statistically significant. Multivariate logistic regression was used for predicting the risk of IDA. Participant age, school cluster, dietary Fe intake and BMI category were included in the model as independent variables. Results were presented as odds ratios with $95 \%$ confidence intervals. A two-sided $P$ value of 0.05 was considered significant. Statistical analyses were performed using the statistical software package SPSS version $15 \cdot 0$ for Windows.

\section{Results}

In the original sample of 1269 adolescent girls, there were 729 with anaemia of whom 414 were eligible according to the inclusion criteria. Of the 414 eligible girls, twelve did not attend school on the blood collection days and data were incomplete for eleven. Therefore data from 391 girls were analysed, and Table 1 shows their general characteristics and nutritional status. Most girls had Burmese ethnicity and were Buddhists. The prevalence of stunting and thinness was $31 \cdot 1$ and $15 \cdot 7 \%$, respectively. Mean usual Fe intake was $11 \cdot 7$ (sD $4 \cdot 8) \mathrm{mg} / \mathrm{d}$. Table 2 shows the percentage of girls with abnormal $\mathrm{Fe}$, vitamin $\mathrm{A}$ and inflammation status indicators. It also shows that correction of Fe and vitamin A data for inflammation using published correction factors had only a very small effect on the prevalence of low Fe and vitamin A status. Both serum retinol and RBP were measured in the present study and there was a significant correlation between the two indicators $(r=0.63, P<0 \cdot 001)$. For the remainder of the current analyses serum retinol concentration is used as the primary indicator of vitamin A status; however, data for RBP are presented in the text and the online supplementary material.

The mean $\mathrm{Hb}$ concentration of the girls was 88.9 (SD 11.8) $\mathrm{g} / \mathrm{l}$ and $30 \cdot 4 \%$ ( $n$ 119) of anaemia was IDA (Table 3). Although the prevalence of vitamin A deficiency (serum retinol $<0.70 \mu \mathrm{mol} / \mathrm{l})$ among the girls was low (1.8\%), the prevalence of low vitamin A status (serum retinol $<1.05 \mu \mathrm{mol} / \mathrm{l})$ was relatively high (31.5\%). Furthermore, there were slightly more girls with low vitamin A status in those with IDA $(37 \cdot 0 \%)$ than in those without IDA $(29 \cdot 0 \%, P=0 \cdot 125)$. SCI, indicated by raised serum CRP 
Table 1 Characteristics of the adolescent schoolgirls ( $n$ 391), delta region of Myanmar, 2010

\begin{tabular}{|c|c|c|c|c|}
\hline Variable & $n$ & $\%$ & Mean & SD \\
\hline Age (years) & & & $15 \cdot 9$ & $1 \cdot 2$ \\
\hline Age at menarche (years) & & & $13 \cdot 2$ & 0.9 \\
\hline \multicolumn{5}{|l|}{ Religion (\%) } \\
\hline Buddhist & 378 & $96 \cdot 7$ & & \\
\hline Christian & 8 & $2 \cdot 0$ & & \\
\hline Hindu & 1 & $0 \cdot 3$ & & \\
\hline Muslim & 4 & $1 \cdot 0$ & & \\
\hline \multicolumn{5}{|l|}{ Ethnicity (\%) } \\
\hline Burmese & 223 & $57 \cdot 0$ & & \\
\hline Kayin & 95 & $24 \cdot 3$ & & \\
\hline Indian & 4 & $1 \cdot 0$ & & \\
\hline Mixed & 69 & $17 \cdot 7$ & & \\
\hline \multicolumn{5}{|l|}{ Father's education status* } \\
\hline Illiterate & 22 & $5 \cdot 6$ & & \\
\hline Primary school & 176 & $45 \cdot 0$ & & \\
\hline Middle school & 108 & $27 \cdot 6$ & & \\
\hline High school & 63 & $16 \cdot 1$ & & \\
\hline Graduate & 12 & $3 \cdot 1$ & & \\
\hline \multicolumn{5}{|l|}{ Mother's education status* } \\
\hline Illiterate & 23 & $5 \cdot 0$ & & \\
\hline Primary school & 222 & $56 \cdot 8$ & & \\
\hline Middle school & 85 & $21 \cdot 7$ & & \\
\hline High school & 44 & $11 \cdot 3$ & & \\
\hline Graduate & 12 & $3 \cdot 1$ & & \\
\hline \multicolumn{5}{|l|}{ Father's occupation status (\%) } \\
\hline Farmer & 210 & $53 \cdot 7$ & & \\
\hline Free labourer & 62 & $15 \cdot 9$ & & \\
\hline Vendor & 41 & $10 \cdot 5$ & & \\
\hline Unemployed & 38 & $9 \cdot 7$ & & \\
\hline Government employee & 30 & $7 \cdot 7$ & & \\
\hline \multicolumn{5}{|l|}{ Mother's occupation status (\%) } \\
\hline Farmer & 141 & $36 \cdot 1$ & & \\
\hline Housewife & 129 & $33 \cdot 0$ & & \\
\hline Vendor & 82 & $20 \cdot 0$ & & \\
\hline Free labourer & 22 & $5 \cdot 6$ & & \\
\hline Government employee & 12 & $3 \cdot 1$ & & \\
\hline \multicolumn{5}{|l|}{ Nutritional status } \\
\hline Weight $(\mathrm{kg})$ & & & $41 \cdot 8$ & $6 \cdot 2$ \\
\hline Height $(\mathrm{m})$ & & & 1.5 & $0 \cdot 1$ \\
\hline BMI $\left(\mathrm{kg} / \mathrm{m}^{2}\right)$ & & & $18 \cdot 3$ & $2 \cdot 3$ \\
\hline \multicolumn{5}{|l|}{ BMI classification by Asian standard } \\
\hline Undernutrition $\left(<18.5 \mathrm{~kg} / \mathrm{m}^{2}\right)$ & 221 & $56 \cdot 5$ & & \\
\hline Normal $\left(18 \cdot 5-22.9 \mathrm{~kg} / \mathrm{m}^{2}\right)$ & 160 & $40 \cdot 9$ & & \\
\hline Overweight $\left(23 \cdot 0-27 \cdot 4 \mathrm{~kg} / \mathrm{m}^{2}\right)$ & 7 & $1 \cdot 8$ & & \\
\hline Obese $\left(\geq 27.5 \mathrm{~kg} / \mathrm{m}^{2}\right)$ & 3 & $0 \cdot 8$ & & \\
\hline Height-for-age Z-score & & & $-1 \cdot 70$ & 0.8 \\
\hline BMI-for-age Z-score & & & $-1 \cdot 19$ & 0.9 \\
\hline Prevalence of stunting (\%)† & 122 & $31 \cdot 1$ & & \\
\hline Prevalence of thinness (\%)† & 61 & $15 \cdot 7$ & & \\
\hline Dietary Fe intake $(\mathrm{mg} / \mathrm{d})$ & & & $11 \cdot 7$ & $4 \cdot 8$ \\
\hline
\end{tabular}

*Ten fathers and five mothers had passed away.

tStunting and thinness defined as height-for-age $Z$-score $<-2$ and BMI-forage $Z$-score $<-2$, respectively.

and/or AGP concentrations, was found in only $6 \cdot 6 \%$ of the girls. Fe, vitamin A and SCI status of the girls were compared between non-IDA and IDA groups; $\mathrm{Hb}$, Fe and vitamin A status indicators were significantly different between the two groups while inflammation status was not.

The effect of SCI on Fe and vitamin A status was investigated by comparing Fe and vitamin A status indicators of the girls in the presence and absence of inflammation (data not shown). Results showed that apart from $\mathrm{Hb}$ and sTfR concentrations, other indicators were significantly different depending on inflammation status. However, since the prevalence of girls with SCI was low, SF and vitamin A data were corrected for the influence of SCI for the remainder of the analyses ${ }^{(13,14)}$ (Table 4, Table 5 and Supplemental Table 2).

Logistic regression was done adjusting for age, clustering by school, Fe intake and BMI category. The results showed that among these anaemic adolescent girls, poor vitamin A status was a significant predictor for IDA. In the two lower vitamin A tertiles (serum retinol $\leq 1.056 \mu \mathrm{mol} / \mathrm{l}$ and $1 \cdot 056-1 \cdot 298 \mu \mathrm{mol} / \mathrm{l}$ ), the risk of IDA was two times higher than in the upper vitamin A tertile (serum retinol $>1 \cdot 298 \mu \mathrm{mol} / \mathrm{l})$. IDA was not significantly associated with other risk factors studied such as age, BMI, clustering by school, Fe intake and inflammation (Table 4). When the analysis was run using RBP (tertiles for RBP were $\leq 1 \cdot 232,1 \cdot 232-1 \cdot 465$ and $>1 \cdot 465 \mu \mathrm{mol} / \mathrm{l})$, the same pattern was observed even though it failed to reach statistical significance and be a significant predictor for IDA (Supplemental Table 1).

Fe status indicators of the girls were compared across tertiles of vitamin A status. For all girls, results showed that all the Fe status indicators except $\mathrm{Hb}$ were significantly different among the tertiles of serum retinol concentrations. $P$ values from ANOVA were $0 \cdot 251,0 \cdot 003$, 0.02 and 0.001 for $\mathrm{Hb}, \mathrm{SF}$, sTfR and body Fe store, respectively (results not shown).

When the girls were stratified by their Fe status (IDA and non-IDA), their vitamin A status did not influence $\mathrm{Hb}$ and STfR for both the IDA and the non-IDA group. However, in the IDA group, poor vitamin A status was significantly associated with low SF concentration and low body Fe stores. The sTfR concentration showed a similar trend but it failed to reach statistical significance. No relationships between the Fe status indicators and vitamin A status were observed in the non-IDA group (Table 5). When the analysis was done using RBP, similar findings were obtained in the IDA group for $\operatorname{SF}(9 \cdot 4,17 \cdot 2$, $16.7 \mu \mathrm{g} / 1 ; P=0 \cdot 04)$ except that differences between body Fe stores $(-1 \cdot 8,0 \cdot 22,0 \cdot 41 \mathrm{mg} / \mathrm{kg}, P=0 \cdot 07)$ failed to reach statistical significance (Supplemental Table 2).

\section{Discussion}

In the present study, we have found that $30 \%$ of anaemia cases were due to ID. More importantly, not only low retinol concentration $(\leq 1.056 \mu \mathrm{mol} / \mathrm{l})$ but also moderate retinol concentration was associated with significantly increased risk of IDA. Among these anaemic adolescent girls, the association between vitamin $\mathrm{A}$ and $\mathrm{Fe}$ status indicators (SF and body Fe stores) was found to be significant only in those with IDA. These findings were consistent when RBP was used instead of serum retinol.

The results from the study suggest that a third of the anaemic adolescent girls have poor $\mathrm{Fe}$ and/or 
Table 2 Abnormal iron, vitamin A and inflammation status biomarkers among adolescent schoolgirls ( $n$ 391), delta region of Myanmar, 2010

\begin{tabular}{|c|c|c|c|c|}
\hline & Median & Range (1st-3rd quartile) & Cut-off & Deficient or abnormal (\%) \\
\hline $\mathrm{Hb}(\mathrm{g} / \mathrm{l})$ & $89 \cdot 7$ & $81 \cdot 1-96 \cdot 7$ & $<120$ & $99 \cdot 5$ \\
\hline $\mathrm{SF}(\mu \mathrm{g} / \mathrm{l})$ & $37 \cdot 5$ & $20 \cdot 6-56 \cdot 5$ & $<15$ & $19 \cdot 9$ \\
\hline MA-corrected SF $(\mu \mathrm{g} / \mathrm{l})^{*}$ & $36 \cdot 9$ & $20 \cdot 2-54 \cdot 2$ & $<15$ & $19 \cdot 9$ \\
\hline Serum sTfR $(\mathrm{mg} / \mathrm{l})$ & $6 \cdot 4$ & $5 \cdot 4-8 \cdot 0$ & $>8.5$ & $16 \cdot 6$ \\
\hline Body Fe store (mg/kg) & 4.9 & $2 \cdot 1-6 \cdot 7$ & $\leq 0$ & $16 \cdot 4$ \\
\hline Serum RBP $(\mu \mathrm{mol} / \mathrm{l})$ & $1 \cdot 3$ & $1 \cdot 2-1 \cdot 6$ & $<0 \cdot 70$ & $1 \cdot 0$ \\
\hline MA-corrected RBP $(\mu \mathrm{mol} / /)^{*}$ & $1 \cdot 4$ & $1 \cdot 2-1 \cdot 6$ & $<1.05$ & $13 \cdot 0$ \\
\hline Serum retinol $(\mu \mathrm{mol} / \mathrm{l})$ & $1 \cdot 2$ & $1 \cdot 0-1 \cdot 4$ & $<0 \cdot 70$ & $1 \cdot 8$ \\
\hline MA-corrected serum retinol $(\mu \mathrm{mol} / \mathrm{l})^{\star}$ & $1 \cdot 2$ & $1 \cdot 0-1 \cdot 4$ & $<1.05$ & $30 \cdot 4$ \\
\hline CRP (mg/l) & $0 \cdot 2$ & $0 \cdot 1-0.3$ & $>5$ & $2 \cdot 6$ \\
\hline AGP $(g / l)$ & $0 \cdot 7$ & $0.6-0.8$ & $>1$ & $6 \cdot 6$ \\
\hline
\end{tabular}

SF, serum ferritin; MA, meta-analysis; sTfR, soluble transferrin receptor; RBP, retinol binding protein; CRP, C-reactive protein; AGP, $\alpha_{1}$-acid glycoprotein. ${ }^{*}$ Correction factors obtained from Thurnham et $a l^{(13,14,31)}$.

Table 3 Iron, vitamin A and inflammation status according to IDA status* among adolescent schoolgirls ( $n$ 391), delta region of Myanmar, 2010

\begin{tabular}{|c|c|c|c|c|c|}
\hline & \multicolumn{2}{|c|}{ Non-IDA ( $n$ 272) } & \multicolumn{2}{|c|}{ IDA $(n$ 119) } & \multirow[b]{2}{*}{$P$ valuet } \\
\hline & Mean & SD & Mean & SD & \\
\hline $\mathrm{Hb}(\mathrm{g} / \mathrm{l})$ & $90 \cdot 9$ & $10 \cdot 9$ & $84 \cdot 3$ & $12 \cdot 5$ & $<0.001$ \\
\hline$S F(\mu g / l)$ & $44 \cdot 1$ & 1.67 & $13 \cdot 5$ & 3.51 & $<0.001$ \\
\hline Serum sTfR (mg/l) & $5 \cdot 75$ & $1 \cdot 22$ & $10 \cdot 34$ & $1 \cdot 6$ & $<0.001$ \\
\hline Body Fe store $(\mathrm{mg} / \mathrm{kg})$ & $5 \cdot 9$ & $2 \cdot 1$ & -0.5 & $4 \cdot 9$ & $<0.001$ \\
\hline Serum RBP $(\mu \mathrm{mol} / \mathrm{l})$ & $1 \cdot 39$ & $0 \cdot 32$ & $1 \cdot 31$ & $0 \cdot 28$ & 0.018 \\
\hline Serum retinol $(\mu \mathrm{mol} / \mathrm{l})$ & $1 \cdot 24$ & 0.33 & $1 \cdot 15$ & $0 \cdot 27$ & 0.013 \\
\hline Vitamin A deficiency (\%)‡ & $0 \cdot \overline{7}$ & & $1 \cdot 7$ & & 0.588 \\
\hline Low vitamin A (\%)§ & $29 \cdot 0$ & & $37 \cdot 0$ & & $0 \cdot 125$ \\
\hline CRP (mg/l) & $0 \cdot 21$ & $4 \cdot 18$ & $0 \cdot 17$ & $3 \cdot 85$ & 0.263 \\
\hline AGP $(g / l)$ & 0.73 & $1 \cdot 24$ & 0.72 & $1 \cdot 26$ & 0.503 \\
\hline $\mathrm{SCI}(\%) \|$ & $7 \cdot 4$ & & $5 \cdot 0$ & & 0.510 \\
\hline
\end{tabular}

IDA, Fe-deficiency anaemia; SF, serum ferritin; sTfR, soluble transferrin receptor; RBP, retinol binding protein; CRP, C-reactive protein; AGP, $\alpha_{1}$-acid glycoprotein; $\mathrm{SCl}$, subclinical inflammation.

${ }^{*}$ Geometric means and standard deviations for SF, serum STfR, CRP and AGP.

tIndependent $t$ test (for continuous variables) or $\chi^{2}$ test (for categorical variables) was used for comparing the Fe and vitamin A status indicators between the groups.

$\ddagger$ Serum retinol $<0.70 \mu \mathrm{mol} / \mathrm{I}$

$\S$ Serum retinol $<1.05 \mu \mathrm{mol} / \mathrm{l}$.

IISCI defined as CRP $>5 \mathrm{mg} / \mathrm{l}$ and/or AGP $>1 \mathrm{~g} / \mathrm{l}$.

Table 4 Risk factors for IDA among adolescent schoolgirls ( $n$ 391), delta region of Myanmar, 2010

\begin{tabular}{|c|c|c|c|}
\hline & OR & $95 \% \mathrm{Cl}$ OR & $P$ value* \\
\hline \multicolumn{4}{|l|}{ Serum retinol } \\
\hline Highest tertile $(>1 \cdot 298 \mu \mathrm{mol} / \mathrm{l})$, ref. & $1 \cdot 000$ & - & $0 \cdot 013$ \\
\hline Lowest tertile $(\leq 1.056 \mu \mathrm{mol} / \mathrm{l})$ & $2 \cdot 314$ & $1 \cdot 314,4 \cdot 073$ & 0.004 \\
\hline Middle tertile $(1 \cdot 056-1 \cdot 298 \mu \mathrm{mol} / \mathrm{l})$ & $1 \cdot 814$ & $1 \cdot 031,3 \cdot 191$ & 0.039 \\
\hline $\mathrm{SClt}$ & 1.592 & $0.595,4.263$ & 0.355 \\
\hline
\end{tabular}

IDA, Fe-deficiency anaemia; ref., reference category; SCI, subclinical inflammation; C-reactive protein; AGP, $\alpha_{1}$-acid glycoprotein. *Logistic regression adjusted for age, school cluster, dietary Fe intake and BMI category, significant at $P<0.05$.

tSCl defined as CRP $>5 \mathrm{mg} / \mathrm{l}$ and/or AGP $>1 \mathrm{~g} / \mathrm{l}$.

vitamin A status. Generally, nutritional status of the girls did not differ much compared with the data reported by the National Nutrition Center ${ }^{(33)}$ but a $31 \cdot 1 \%$ prevalence of stunting is relatively high and represents the existence of chronic nutritional problems among the population. More than half $(56 \cdot 5 \%)$ of the girls were underweight according to their BMI. In previous surveys in Myanmar, the Fe status of the population was not comprehensively studied and $\mathrm{Hb}$ only was used as a proxy indicator of ID. The prevalence of anaemia among adolescents was reported to be $26.0 \%$ according to data from the National Nutrition Center ${ }^{(33)}$. ID was assumed to be the main cause 
Table 5 Comparison of mean $\mathrm{Hb}$ and iron status indicators across different serum retinol tertiles stratified by IDA status ${ }^{*}+$ among adolescent schoolgirls ( $n$ 391), delta region of Myanmar, 2010

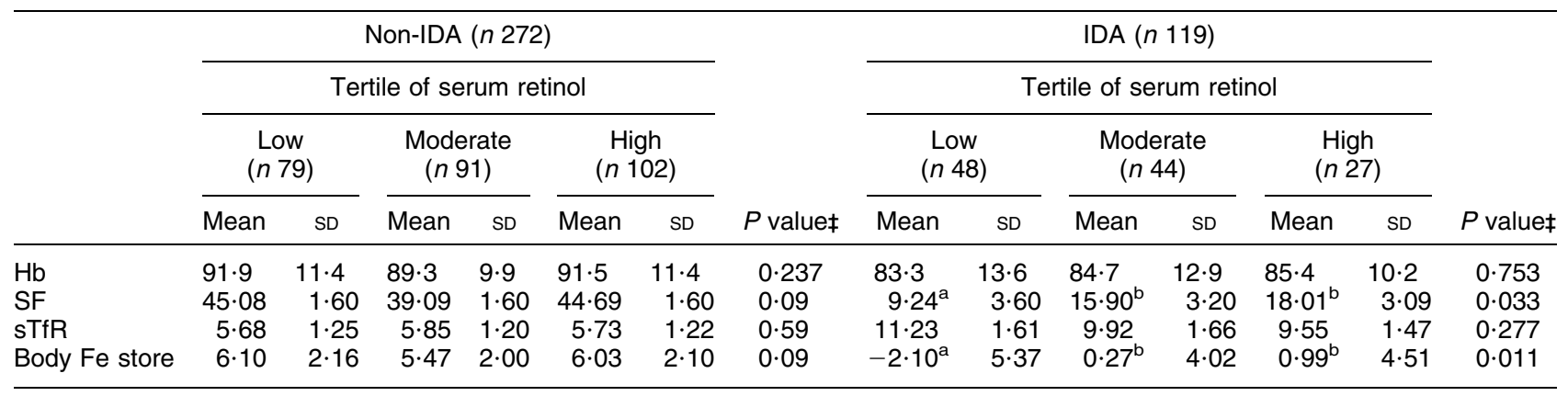

IDA, Fe-deficiency anaemia; SF, serum ferritin; sTfR, soluble transferrin receptor.

${ }^{a, b}$ Mean values within a row with unlike superscript letters were significantly different $(P<0.05)$.

*Vitamin A status classified by serum retinol tertile (lowest tertile $\leq 1 \cdot 056 \mu \mathrm{mol} / \mathrm{l}$, middle tertile $1 \cdot 056-1 \cdot 298 \mu \mathrm{mol} / \mathrm{l}$ and highest tertile $>1 \cdot 298 \mu \mathrm{mol} / \mathrm{l}$ ).

tMean and standard deviation for $\mathrm{Hb}$ and body Fe store, geometric mean and standard derivation for SF and STfR.

‡One-way ANOVA, with post hoc analysis done using least significant difference.

of anaemia in the region and in the country at large. The findings from our study suggest that poor vitamin A may also be an important contributor to anaemia in Myanmar. The prevalence of ID among the anaemic adolescent girls in our study is comparable to that in other countries in South-East Asia. In Bangladesh, Thailand and Indonesia, the prevalence of ID was reported to be $33.0 \%, 21.5 \%$ and $27 \cdot 3 \%$, respectively ${ }^{(7,20,34-36)}$. In Vietnam, the prevalence of ID among women of reproductive age was reported to be as low as $8.9 \%$ while it contributed as high as $42 \%$ among adolescent Kenyan girls with anaemia ${ }^{(12,37)}$ suggesting that it is an important determinant. However, there is evidence for the coexistence of multiple micronutrient deficiencies in the Asian countries ${ }^{(6,7)}$ and therefore it is important that the status of other micronutrients, such as vitamin $\mathrm{B}_{12}$ and folate, be properly examined in attempts to control anaemia.

Inflammation was not very prevalent among our study population and only $6.7 \%$ displayed evidence of SCI. Inflammation is the body's physiological response to infections and injuries and the purpose is to minimise damage to body tissues, although it can have negative implications for nutritional assessment ${ }^{(38,39)}$. However the low prevalence of SCI meant that inflammation had little impact on nutritional biomarkers in the present study (Table 2). The results also suggest that sTfR concentrations were not affected by SCI although other workers have reported different results ${ }^{(40-42)}$. The prevalence of SCI will depend on the intensity of infections and the age of the individuals. For example, a recent study from Cambodia showed SCI (i.e. elevated AGP) was a significant risk factor for anaemia among young children $^{(16)}$. Similarly, another study from Papua New Guinea highlighted that SCI (i.e. elevated CRP and AGP) among children under 5 years old was significantly associated with the high prevalence of anaemia ${ }^{(43)}$. However, in a study conducted among pre-school children from the Marshall Islands, it was reported that both Fe and vitamin A deficiencies, but not inflammation, were independent risk factors for anaemia ${ }^{(44)}$. Our study in Myanmar suggests that poor vitamin A status was the significant predictor of ID whereas inflammation was not.

Logistic regression showed a twofold higher risk of IDA when the concentration of serum retinol was in the middle and lower tertiles (Table 4). This finding suggests that good vitamin A status may be necessary to prevent ID. The interdependence of vitamin $\mathrm{A}$ and Fe has been reported in previous studies. Blackfan and Wolbach reported that anaemia as well as haemosiderosis of the spleen and liver could be reversed by repletion with vitamin A in vitamin A-deficient patients ${ }^{(45)}$. Anaemia refractory to $\mathrm{Fe}$ supplementation but responsive to vitamin A was reported among vitamin A-deficient, healthy volunteers by Hodges et al. ${ }^{(46)}$. A study from Guatemala indicated that vitamin A was probably important in mobilising Fe stores where a vitamin A-fortified sugar programme was implemented among pre-school children ${ }^{(47)}$. A randomised controlled trial from Indonesia showed an increase in SF concentrations by $14.9 \mu \mathrm{g} / \mathrm{l}$ when vitamin A-deficient children were treated with vitamin A supplements ${ }^{(48)}$. These studies suggest that vitamin A may directly enhance erythropoiesis as well as the mobilisation of Fe from storage. Similarly, other studies have confirmed the beneficial effect of additional vitamin A to Fe supplementation ${ }^{(10,11,49,50)}$ while others found no benefit ${ }^{(12,51,52)}$.

Further analysis of $\mathrm{Fe}$ status in the vitamin A tertiles showed that Fe status was better in the two groups with the higher vitamin A status (i.e. serum retinol $>1.056 \mu \mathrm{mol} / \mathrm{l}$ ). Similar findings were reported before, where higher $\mathrm{Hb}$ concentrations were associated with better vitamin A status ${ }^{(44,46)}$. However, when we stratified the anaemic girls by their Fe status, the association did not exist in the nonIDA group whereas it was maintained in the IDA group (Table 5). This finding is interesting since it might explain the inconsistent findings where Fe-deficient and non Fe-deficient anaemic subjects are not considered separately. Many studies have shown the positive effect of vitamin A in reducing the prevalence of anaemia but not all ${ }^{(12,51,52)}$, and 
this inconsistency might be better explained if the association of Fe and vitamin A status is taken into account.

Our findings showed that poor Fe and vitamin A status contributed to anaemia among adolescent schoolgirls in Myanmar but it could not explain the full extent of the high prevalence of anaemia among the girls. The girls in the study were apparently healthy and anaemia due to infections or inflammations was unlikely given the low prevalence of inflammatory biomarkers among the girls. In the region, multiple micronutrient deficiencies frequently coexist and the role of other micronutrients such as vitamin $\mathrm{B}_{12}$ and folate should also be carefully considered and explored further ${ }^{(6,8,53)}$. It would appear that improvements in vitamin A status may be required to reduce IDA and should be considered as part of programme implementation even though clinical vitamin A deficiency does not appear to be a public health problem in the region studied.

\section{Acknowledgements}

Sources of funding: This study was funded by a DAAD (German Academic Exchange Service) scholarship and the Nestlé Foundation. DAAD and Nestlé Foundation had no influence in the design or analysis of the study, writing of this article or the decision to submit it for publication. Conflicts of interest: No author has any conflict of interest. Authors' contributions: M.K.H., D.D., A.A., B.U., U.F. and D.I.T. designed the research; M.K.H. conducted the research; M.K.H., U.F. and D.I.T. analysed the data; M.K.H., U.F. and D.I.T. wrote the paper and M.K.H. had primary responsibility for the final content. All authors read and approved the final manuscript. Acknowledgements: The authors thank Director General Dr Myo Khin from the Department of Medical Research, Lower Myanmar; Dr Theingi Thwin, Deputy Director, and team from the Nutrition Research Division, Department of Medical Research, Lower Myanmar for biochemical data collection; and Dr J.G. Erhardt for analyses of RBP, SF, sTfR, CRP and AGP and discussions.

\section{Supplementary material}

To view supplementary material for this article, please visit http://dx.doi.org/10.1017/S1368980013002723

\section{References}

1. World Health Organization (2006) Adolescent Nutrition: A Review of the Situation in Selected South-East Asian Countries. New Delhi: WHO Regional Office for South-East Asia.

2. McLean E, Cogswell M, Egli I et al. (2008) Worldwide prevalence of anaemia, WHO Vitamin and Mineral Nutrition Information System, 1993-2005. Public Health Nutr 12, 444-454.

3. Ronnenberg AG, Wood RJ, Wang X et al. (2004) Preconception hemoglobin and ferritin concentrations are associated with pregnancy outcome in a prospective cohort of Chinese women. J Nutr 134, 2586-2591.

4. Casanueva E, Pfeffer F, Drijanski A et al. (2003) Iron and folate status before pregnancy and anemia during pregnancy. Ann Nutr Metab 47, 60-63.

5. Htet MK, Dillon D, Akib A et al. (2012) Microcytic anaemia predominates in adolescent school girls in the delta region of Myanmar. Asia Pac J Clin Nutr 21, 411-415.

6. Winichagoon P (2008) Coexistence of micronutrient malnutrition: implication for nutrition policy and programs in Asia. Asia Pac J Clin Nutr 17, Suppl. 1, 346-348.

7. Ahmed F, Khan MR, Banu CP et al. (2008) The coexistence of other micronutrient deficiencies in anaemic adolescent schoolgirls in rural Bangladesh. Eur J Clin Nutr 62, 365-372.

8. Thurlow RA, Winichagoon P, Green T et al. (2005) Only a small proportion of anemia in northeast Thai schoolchildren is associated with iron deficiency. Am J Clin Nutr 82, 380-387.

9. Semba R \& Bloem M (2002) The anemia of vitamin A deficiency: epidemiology and pathogenesis. Eur J Clin Nutr 56, 271-281.

10. Suharno D, West CE, Karyadi D et al. (1993) Supplementation with vitamin A and iron for nutritional anaemia in pregnant women in West Java, Indonesia. Lancet $\mathbf{3 4 2}$, $1325-1328$.

11. Ahmed F, Khan MR \& Jackson AA (2001) Concomitant supplemental vitamin A enhances the response to weekly supplemental iron and folic acid in anemic teenagers in urban Bangladesh. Am J Clin Nutr 74, 108-115.

12. Leenstra T, Kariuki SK, Kurtis JD et al. (2009) The effect of weekly iron and vitamin A supplementation on hemoglobin levels and iron status in adolescent schoolgirls in western Kenya. Eur J Clin Nutr 63, 173-182.

13. Thurnham DI, McCabe LD, Haldar S et al. (2010) Adjusting plasma ferritin concentrations to remove the effects of subclinical inflammation in the assessment of iron deficiency: a meta-analysis. Am J Clin Nutr 92, 546-555.

14. Thurnham DI, McCabe GP, Northrop-Clewes CA et al. (2003) Effects of subclinical infection on plasma retinol concentrations and assessment of prevalence of vitamin A deficiency: meta-analysis. Lancet 362, 2052-2058.

15. World Health Organization \& Centers for Disease Control and Prevention (2005) Assessing the Iron Status of Populations: Report of a Joint World Health Organization/Centers for Disease Control and Prevention Technical Consultation on the Assessment of Iron Status at the Population Level, Geneva, Switzerland, 6-8 April 2004. Geneva: WHO, Department of Nutrition for Health and Development.

16. George J, Yiannakis M, Main B et al. (2012) Genetic hemoglobin disorders, infection, and deficiencies of iron and vitamin A determine anemia in young Cambodian children. J Nutr 142, 781-787.

17. Weatherall DJ (2008) Hemoglobinopathies worldwide: present and future. Curr Mol Med 8, 592-599.

18. Ministry of Health (2012) Health in Myanmar. Nay Pyi Taw, Myanmar: Ministry of Health.

19. Department of Health Planning (2011) Annual Hospital Statistics Report. Nyi Pyi Taw, Myanmar: Department of Health, Ministry of Health.

20. Angeles-Agdeppa I, Schultink W, Sastroamidjojo S et al. (1997) Weekly micronutrient supplementation to build iron stores in female Indonesian adolescents. Am J Clin Nutr 66, $177-183$

21. Casey GJ, Phuc TQ, Macgregor L et al. (2009) A free weekly iron-folic acid supplementation and regular deworming program is associated with improved hemoglobin and iron status indicators in Vietnamese women. BMC Public Health 9, 261 
22. Rohner F, Zimmermann MB, Amon RJ et al. (2010) In a randomized controlled trial of iron fortification, anthelmintic treatment, and intermittent preventive treatment of malaria for anemia control in Ivorian children, only anthelmintic treatment shows modest benefit. $J$ Nutr $\mathbf{1 4 0 ,}$ 635-641.

23. Erhardt JG, Mack H, Sobeck U et al. (2002) $\beta$-Carotene and $\alpha$-tocopherol concentration and antioxidant status in buccal mucosal cells and plasma after oral supplementation. $B r J N u t r \mathbf{8 7}, 471-475$.

24. Erhardt JG, Estes JE, Pfeiffer CM et al. (2004) Combined measurement of ferritin, soluble transferrin receptor, retinol binding protein, and C-reactive protein by an inexpensive, sensitive, and simple sandwich enzyme-linked immunosorbent assay technique. J Nutr 134, 3127-3132.

25. Cook JD, Flowers CH \& Skikne BS (2003) The quantitative assessment of body iron. Blood 101, 3359-3363.

26. Cogswell ME, Looker AC, Pfeiffer CM et al. (2009) Assessment of iron deficiency in US preschool children and nonpregnant females of childbearing age: National Health and Nutrition Examination Survey 2003-2006. Am J Clin Nutr 89, 1334-1342.

27. Gibson R (2005) Principles of Nutritional Assessment. New York: Oxford University Press.

28. World Health Organization (2001) Iron Deficiency Anaemia: Assessment, Prevention, and Control. A Guide for Programme Managers. Geneva: WHO.

29. Northrop-Clewes CA (2008) Interpreting indicators of iron status during an acute phase response - lessons from malaria and human immunodeficiency virus. Ann Clin Biochem 45, 18-32.

30. West KP (2002) Extent of vitamin A deficiency among preschool children and women of reproductive age. $J$ Nutr 132, 9 Suppl., 2857S-2866S.

31. Thurnham DI, Mburu AS, Mwaniki DL et al. (2005) Micronutrients in childhood and the influence of subclinical inflammation. Proc Nutr Soc 64, 502-509.

32. World Health Organization (2009) WHO AnthroPlus for Personal Computers Manual: Software for Assessing Growth of the World's Children and Adolescents. Geneva: WHO.

33. National Nutrition Center (2002) National Haemoglobin and Nutritional Status Survey Among Adolescents. Yangon, Myanmar: National Nutrition Center, Department of Health, Ministry of Health.

34. Ahmed F, Khan MR, Akhtaruzzaman M et al. (2010) Long-term intermittent multiple micronutrient supplementation enhances hemoglobin and micronutrient status more than iron + folic acid supplementation in Bangladeshi rural adolescent girls with nutritional anemia. J Nutr 140, 1879-1886.

35. Kurniawan YAI, Muslimatun S, Achadi EL et al. (2006) Anaemia and iron deficiency anaemia among young adolescent girls from the peri urban coastal area of Indonesia. Asia Pac J Clin Nutr 15, 350-356.

36. Sungthong R, Mo-suwan L, Chongsuvivatwong $\mathrm{V}$ et al. (2002) Once weekly is superior to daily iron supplementation on height gain but not on hematological improvement among schoolchildren in Thailand. J Nutr 132, 418-422.

37. Berger J, Thanh HTK, Cavalli-Sforza T et al. (2005) Community mobilization and social marketing to promote weekly iron-folic acid supplementation in women of reproductive age in Vietnam: impact on anemia and iron status. Nutr Rev 63, 12 Pt 2, S95-S108.

38. Thurnham D \& Northrop-Clewes CA (2004) Effects of infection on nutritional and immune status. In Diet and Immune Function, pp. 35-64 [DA Hughes, G Darlington and A Bendich, editors]. Totowa, NJ: Humana Press.

39. Wieringa FT, Dijkhuizen MA, West CE et al. (2002) Estimation of the effect of the acute phase response on indicators of micronutrient status in Indonesian infants. $J$ Nutr 132, 3061-3066.

40. Beesley R, Filteau S, Tomkins A et al. (2000) Impact of acute malaria on plasma concentrations of transferrin receptors. Trans R Soc Trop Med Hyg 94, 295-298.

41. Kung'u JK, Wright VJ, Haji HJ et al. (2009) Adjusting for the acute phase response is essential to interpret iron status indicators among young Zanzibari children prone to chronic malaria and helminth infections. J Nutr 139, 2124-2131.

42. Williams T, Maitland K, Rees D et al. (1999) Reduced soluble transferrin receptor concentrations in acute malaria in Vanuatu. Am J Trop Med Hyg 60, 875-878.

43. Shinoda N, Sullivan KM, Tripp K et al. (2013) Relationship between markers of inflammation and anaemia in children of Papua New Guinea. Public Health Nutr 16, 289-295.

44. Gamble MV, Palafox NA, Dancheck B et al. (2004) Relationship of vitamin A deficiency, iron deficiency, and inflammation to anemia among preschool children in the Republic of the Marshall Islands. Eur J Clin Nutr 58, 1396-1401.

45. Blackfan KD \& Wolbach SB (1933) Vitamin a deficiency in infants: a clinical and pathological study. $J$ Pediatr $\mathbf{3}$, 679-706.

46. Hodges R, Sauberlich H, Canham J et al. (1978) Hematopoietic studies in vitamin A deficiency. Am J Clin Nutr 31, 876-885.

47. Mejia L \& Arroyave G (1982) The effect of vitamin A fortification of sugar on iron metabolism in preschool children in Guatemala. Am J Clin Nutr 36, 87-93.

48. Semba RD, Muhilal MPH, West KP Jr et al. (1992) Impact of vitamin a supplementation on hematological indicators of iron metabolism and protein status in children. Nutr Res 12, 469-478.

49. Mwanri L, Worsley A, Ryan P et al. (2000) Supplemental vitamin A improves anemia and growth in anemic school children in Tanzania. J Nutr 130, 2691-2696.

50. Ma AG, Schouten EG, Zhang FZ et al. (2008) Retinol and riboflavin supplementation decreases the prevalence of anemia in Chinese pregnant women taking iron and folic acid supplements. J Nutr 138, 1946-1950.

51. Semba RD, Kumwenda N, Taha TE et al. (2001) Impact of vitamin A supplementation on anaemia and plasma erythropoietin concentrations in pregnant women: a controlled clinical trial. Eur J Haematol 66, 389-395.

52. Soekarjo DD, Pee Sd, Kusin JA et al. (2004) Effectiveness of weekly vitamin A (10,000 IU) and iron $(60 \mathrm{mg})$ supplementation for adolescent boys and girls through schools in rural and urban East Java, Indonesia. Eur J Clin Nutr 58, 927-937.

53. Anderson VP, Jack S, Monchy D et al. (2008) Co-existing micronutrient deficiencies among stunted Cambodian infants and toddlers. Asia Pac J Clin Nutr 17, 72-79. 